\title{
Thermoregulation in the large carpenter bee Xylocopa frontalis in the face of climate change in the Neotropics
}

\author{
Felipe Jackson de Farias-Silva, Breno M. Freitas \\ Setor de Abelhas, Departamento de Zootecnia, Centro de Ciências Agrárias, Universidade Federal do Ceará, Fortaleza, \\ CE 60.356-000, Brazil
}

Received 13 April 2020 - Revised 28 September 2020 - Accepted 28 October 2020

\begin{abstract}
There is evidence that climate change may worsen the ecological conditions needed by many pollinator species for their survival; however, little is known about how the rise in ambient temperature might affect the survival of large bee species in tropical regions of the planet. This study investigated the thermoregulation mechanisms of the large carpenter bee Xylocopa frontalis when nesting spontaneously in nests designed to allow direct measurement of the bees' temperature while carrying out different activities. It was seen that the species divides its activities throughout the day according to the amount of body heat generated and the ambient temperature, performing activities that generate more body heat at cooler times of the day. The bees also use strategies of thermoregulation, such as heat loss by air convection, evaporative cooling by nectar dehydration, and not foraging during the hottest times of the day to avoid overheating. The study shows that $X$. frontalis is well adjusted to the ecological conditions of the areas in which it lives but suggests that future rises in the ambient temperature could pose a serious threat to the survival and pollination services provided by this bee and other similar tropical species.
\end{abstract}

body temperature/ foraging strategy/global warming/behavioural thermoregulation/thermoregulation in the tropics

\section{INTRODUCTION}

Pollinators are essential for the reproduction of wild plants and for food production around the world, with approximately $35 \%$ of agricultural production and $87.5 \%$ of flowering plants depending to some degree on these agents (Klein et al. 2007, Klein et al. 2020; Ollerton et al. 2011; Potts et al. 2016). However, pollinators are in decline all over the world due to a variety of reasons,

Corresponding author: F. Farias-Silva, felipe.jackson2@gmail.com

Manuscript Editor: Klaus Hartfelder such as habitat loss and fragmentation, pests, diseases, invasive species, pesticides and climate change (Freitas et al. 2009; Meeus et al. 2012; Potts et al. 2016; Brown et al. 2016).

Among these, climate change is worrisome, as it can compromise pollination services on a global scale via isolated extreme events, such as fires, storms and hurricanes, but mainly due to global warming and a gradual rise in the mean temperature in different regions of the planet. Such events can compromise the survival of pollinators, leading to significant reductions in population (Freitas et al. 2009; Rasmont and Iserbyt 2012; Oliver et al. 2015; Brown et al. 2016), or to temporal mismatch between pollinators and the flowering of crops, which 
represents a great risk to agricultural production and food security (Settele et al. 2016; Bezerra et al. 2019a).

Bees are considered the principal pollinators, and there is evidence that climate change, especially global warming, may worsen the ideal ecological conditions of many species, leading to local extinctions and a reduction in areas of natural occurrence (Herrera et al. 2014; Polce et al. 2014; Giannini et al. 2013, 2017; Elias et al. 2017; Bezerra et al. 2019a; Soroye et al. 2020). According to the International Panel on Climate Change (IPCC) (2013), an increase of between 0.3 and 4.8 ${ }^{\circ} \mathrm{C}$ in mean global temperature may occur by 2080. Although social bees may have difficulties in dealing with this phenomenon, populations of solitary bees are at greater risk of being affected, as they depend more on the ambient temperature to regulate body heat and go through their hibernation/aestivation cycles (Stone 1993, 1994; Heinrich and Esch 1994; Bartomeus et al. 2011). However, investigation into the potential impact of climate change on bees is usually focused on small solitary species native to temperate regions of the planet (Stone 1993; Bishop and Armbruster 1999; Bartomeus et al. 2011; Soroye et al. 2020).

One of the few studies carried out with large bees in a tropical environment was conducted by Bezerra et al. (2019a) and showed that increases between 0.3 and $4.8^{\circ} \mathrm{C}$ in mean temperature due to climate change, as predicted by the IPCC (2013), may reduce by 47.9 and $35.3 \%$ the areas suitable for survival of the carpenter bee Xylocopa frontalis (Olivier 1789) and X. grisescens (Lepeletier 1841) respectively by 2080. Large species of genus Xylocopa are essential pollinators of wild and cultivated plants with large flowers, such as crotalaria (Crotalaria juncea L.), passion fruit (Passiflora edulis L.), Brazil nut (Bertholletia excelsa Humb. \& Bonpl.), annatto (Bixa orellana L.) and pitaya (Hylocereus spp.), as their size enables the reproductive structures of these flowers to be reached while the bees perform or improve pollination, with consequent results on the quantity and quality of the produced fruit (Freitas et al. 2017; Cavalcante et al. 2018; Muniz et al. 2019; Klein et al. 2020). These bees are also important pollinators for those plant species that rely on buzz pollination, such as crotalaria and annatto.

As $X$. frontalis and $X$. grisescens are large species, and the females are predominantly black despite living in tropical regions, difficulties in thermoregulating their body temperature due to predicted increases in the mean ambient temperature may be related to the anticipated reduction in areas suitable for these species, as suggested by Bezerra et al. (2019a). In fact, Chappell (1982) found that $X$. californica changes its foraging pattern once the ambient temperature exceeds 41 ${ }^{\circ} \mathrm{C}$, a value that is normal at the hottest times of the day in some areas of the Brazilian countryside (Giannini et al. 2017; INMET 2020). However, there are no records of $X$. frontalis being found where the maximum ambient temperature regularly reaches $35^{\circ} \mathrm{C}$ or higher.

Thermoregulation in Xylocopa has been little studied, and there is a lack of information under tropical conditions or situations of free nesting. These bees nest by excavating galleries inside dead wood (Gimenes et al. 2006; Marchi and Melo 2010; Junqueira et al. 2013; Silva et al. 2014), thereby preventing access for their body temperature to be measured inside the nest. As such, the few existing studies were conducted in laboratories or even in the field, with the bees kept in confined environments or attached to equipment for measuring body temperature and body heat (Baird 1986; Heinrich and Buchmann 1986; Volynchik et al. 2006). Restricting individuals invariably causes stress, contributing to a rise in temperature, and potentially leading to overestimated results (Stabentheiner et al. 2007).

However, recent studies have proposed models of nesting devices (trap nests) for breeding Xylocopa bees that allow adult individuals inside the nests to be observed and accessed (Oliveira-Filho and Freitas 2003; Freitas and Oliveira-Filho 2003; Pereira and Garófalo 2010; Junqueira et al. 2013; Maués et al. 2015; Silva and Freitas 2018). One such model consists of a simple wooden bar where the bees build their nests and might reuse for up to three generations (Bezerra 2018). With this model, it is possible to observe the bee performing its daily activities inside the nest, allowing the temperature of the bee to be 
measured using a thermal imager and laser thermometer.

The present study attempted to investigate thermoregulation in Xylocopa frontalis nesting freely in nests that allow the direct measurement of their body temperature when performing the various activities necessary for their survival and reproduction in a given environment. The aim was to investigate the thermoregulation processes of these bees in a hot environment without the stress caused when they are restrained and attempt to understand how these processes are related to the predicted reductions in areas where $X$. frontalis occurs, due to a rise in the mean ambient temperature in the near future. This study can help in understanding how climate change may affect large bees in the tropical regions of the planet.

\section{MATERIAL AND METHODS}

\subsection{Study area}

The study was carried out during August, September, October and December 2018, and January and February 2019, at the Bee Unit of the Federal University of Ceará, in the city of Fortaleza, Brazil $\left(03^{\circ} 43^{\prime} 02^{\prime \prime} \mathrm{S}\right.$ and $38^{\circ} 32^{\prime} 35^{\prime \prime} \mathrm{W}$, at an altitude of $16 \mathrm{~m})$ (IPECE 2019).

Fortaleza is located in the coastal region of the state of Ceará. The climate is hot tropical subhumid, with a rainy period from January to May, a mean annual rainfall of $1338.0 \mathrm{~mm}$, a mean temperature of $26.9{ }^{\circ} \mathrm{C}$ and a mean annual minimum and maximum of 23.6 and $30.4{ }^{\circ} \mathrm{C}$ respectively; the relative humidity is $78 \%$, with $2856.5 \mathrm{~h}$ of sunshine per year and a wind speed of $3.7 \mathrm{~m} / \mathrm{s}$ (IPECE 2019).

The carpenter bees used in this experiment belong to species Xylocopa frontalis, common in the Neotropics, and found in areas with maximum temperatures that reach $35{ }^{\circ} \mathrm{C}$ or less (Figure 1). They were housed in nests built of wooden bars placed in a bee breeding facility (Xylocopary), and in a similar, but smaller structure, in a small forest fragment, both located within the area of the Bee Unit. The Xylocopary consists of a 5-m $\times 15-\mathrm{m}$ structure, build in a wooden shed and covered with tiles of fibre cement. The forest is a remnant of native vegetation, characterised as a vegetation complex of the Coastal Zone, of approximately $7000 \mathrm{~m}^{2}$. The breeding facility located there is similar to the Xylocopary, but much smaller, measuring $1 \mathrm{~m} \times$ $1.65 \mathrm{~m}$.

\subsection{Xylocopa nests}

The nests used in the experiment were based on the model used by Bezerra (2018) and consist of $30 \mathrm{~cm} \times 5 \mathrm{~cm} \times 5 \mathrm{~cm}$ bars of pinewood, giving a total volume in the wood of $750 \mathrm{~cm}^{3}$. Pinus was chosen for the experiment, as it is a relatively soft substrate, facilitating excavation by the carpenter bees. Each wooden bar had a perforation, $2 \mathrm{~cm}$ in diameter, with depths that varied from 3 to $11 \mathrm{~cm}$ to stimulate nesting. The bars were stacked and grouped to form blocks consisting of several nests (Figure 2). During the experiment, a minimum of 23 and a maximum of 36 nests were inhabited at any one time, and measurements were taken randomly as the bees were performing some of the activities under investigation, during the days and times of observation.

\subsection{Thermographic analysis}

Being linear, the nest used made it possible to take infrared images of the bees carrying out their activities in and around the nest throughout the day, in order to carry out the thermographic analysis. For this purpose, a HOT TEC $®$ HT31 Thermal Imager was used with an FPA (Focal Plane Array) uncooled microbolometric detector with a resolution of 19,200 pixels, accuracy of $2 \%$ and thermal sensitivity of $0.06{ }^{\circ} \mathrm{C}$, which was aimed directly at the bee inside or near the nest to record the body temperature.

Ranges of body temperature were measured for the different types of bee behaviour, i.e. at rest inside the nest, returning from the field after foraging, excavating the wood to build the nest/cells, dehydrating nectar, and during the process of warming up the flight musculature (pre-flight warm-up) before leaving for the field. The value for emissivity used to calibrate the thermal imager in the experiment was 0.97 , the same as previously determined in other bee species (Stabentheiner and Schmaranzer 1987). 


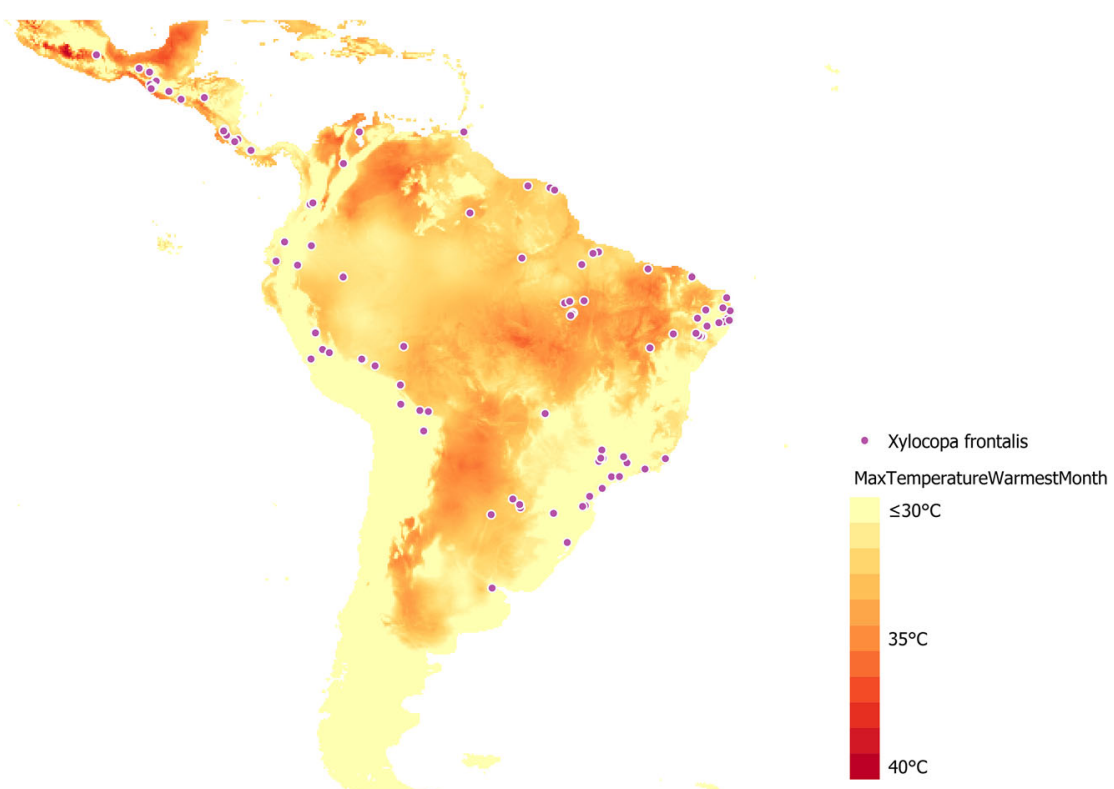

Figure 1. Thermal map of maximum ambient temperatures in the Neotropics and records of the occurrence of Xylocopa frontalis. No occurrence is seen in areas where the maximum ambient temperature reaches $35{ }^{\circ} \mathrm{C}$ or higher. Sources: Fick and Hijmans (2017), Bezerra et al. (2019b).

The measurements were made in periods of $3 \mathrm{~h}$ (04:30 to $07: 30,07: 30$ to $10: 30,10: 30$ to $13: 30$, 13:30 16:30 and 16:30 to 19:30). The bees were observed for only one of these periods each day, drawn the previous evening, taking care to avoid repeating any time period in any one week, so that measurements for that week were taken at a different time each day. The observations were made from Monday to Friday, giving a total of $15 \mathrm{~h}$ observation per week. These time intervals include the entire period of activities performed by the bees during the day under the conditions of the study. Measurements were taken with the observer positioned in front of the nests so as to see all of them and take thermal pictures every time a bee presented any of the above behaviour. As each nest has only one adult bee for most of the time, it was possible to avoid pseudoreplication, recording each bee only once for a given behaviour per period of observation. The data were
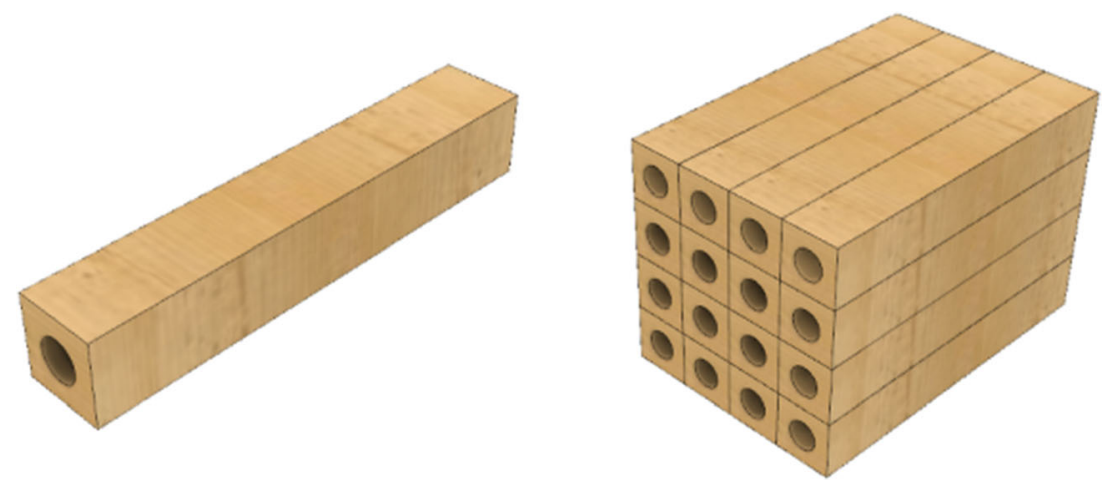

Figure 2. Schematic representation of the nests used for Xylocopa frontalis. 
collected during the first and third weeks of each month, for 6 months, three during the dry season and three during the rainy season, for a total sampling period of $180 \mathrm{~h}$. This period includes the peak of the dry season (August, September and October), characterised by an abundance of resources in the field, and the start of the rainy season (December, January and February) when the rainfall regime does not yet interfere in the bees' period of activity. Each measurement was recorded as a thermal picture, and a total of 3626 pictures were taken. Of these, 784 images (imprecise bee identity, bee behaviour, possible pseudoreplications and images not showing the bee thorax) were discarded, leaving 2842 images to be processed.

The IR Reporter® software was used to analyse the images generated by the thermal imager. Circular or rectangular shapes were created around the thorax, the head or the abdomen of the bee, approximating their shape as much as possible, but ensuring that only bee pixels were selected (Volynchik et al. 2006). From these figures, it was possible to determine the minimum, maximum and mean temperature of the bee. On many occasions, images of each part of the bee's body (head, thorax and abdomen) could not be taken, as the bees were entirely or partially inside, or entering, the nests, and only one or two body parts could be seen. As a result, a mean body temperature was used in the study, calculated by considering only images where at least the thorax and head or thorax and abdomen were visible, as the thorax generates heat and is generally hotter than the head or the abdomen. In addition, weather data for the period (mean ambient temperature: $27.56{ }^{\circ} \mathrm{C}$; maximum ambient temperature: 33.4 ${ }^{\circ} \mathrm{C}$; relative humidity: $68.5 \%$; solar radiation: $4333.76 \mathrm{~kJ} \mathrm{~m}^{-2}$; rainfall: $77.15 \mathrm{~mm}$; wind speed $2.77 \mathrm{~m} \mathrm{~s}^{-1}$ ) were obtained from the Weather Station of the Federal University of Ceará, located $500 \mathrm{~m}$ from the study site.

\subsection{Statistical analysis}

After processing the images, the data were tabulated. Variations in the mean, minimum and maximum body temperature, and the ambient temperature were analysed between the different types of bee behaviour. The variations in temperature were also verified between the months of study, the time of day and the location of the nests. The Kruskal and Wallis (1952) was applied to check whether the temperatures differed significantly (at a level of 5\%) between behaviour types, the months of study, the time of day or nest location. This test was used due to the non-normality of the data and the presence of outliers. When the Kruskal-Wallis test was significant for variables of more than two categories, Dunn's post hoc test (Dunn 1964) was applied to check for significant differences. The same statistical tests were used to analyse how the temperatures varied between behaviour types over the months of the study, time of day and nest location.

\section{RESULTS}

Among the types of behaviour observed in this study for which the body temperatures of the bees were taken, the most frequent was resting inside the nest, comprising the majority of the observed events, followed by returning from the field after foraging, pre-flight warm-up, nectar dehydration and others (Table I; Figure 3).

This behaviour occurred at all times of the day; however, different types of behaviour were concentrated at certain times (Table I, Figure 4). During the cooler hours of the day, the bees gave preference to the activities of returning from the field after foraging, excavating the nest and preflight warm-up. At the hottest times, it was possible to find a greater number of bees at rest or working on nectar dehydration (Figure 4).

Despite finding that the carpenter bees preferred foraging activities during periods of the day with milder temperatures, especially in the early morning, it was also possible to see such activities being carried out during the hottest hours, when the temperature was greater than 37 ${ }^{\circ} \mathrm{C}$ (Table II), although far less frequently.

The pre-flight warm-up was most often seen before and during the first hours after sunrise, generally when the ambient temperature was still below $30{ }^{\circ} \mathrm{C}$ (Table II). At all times, the bees reached a mean body temperature greater than $30{ }^{\circ} \mathrm{C}$ before beginning their flight (Table III). On the other hand, nest excavation, although also 
Table I. Number of events and percentage value for body temperature recorded for some types of behaviour in Xylocopa frontalis throughout the day, in Fortaleza, Ceará, Brazil, from August 2018 to February 2019

\begin{tabular}{lllllll}
\hline \multirow{2}{*}{ Time } & \multicolumn{7}{c}{ Behaviour } \\
\cline { 2 - 7 } & \multicolumn{1}{c}{$D N(\%)$} & \multicolumn{1}{c}{$E(\%)$} & $P A(\%)$ & \multicolumn{1}{c}{$R(\%)$} & $V C(\%)$ & $O(\%)$ \\
\hline 04:30-07:30 & $5(10.0)$ & $3(4.7)$ & $52(69.3)$ & $386(17.0)$ & $124(33.3)$ & $0(0.0)$ \\
$07: 30-10: 30$ & $6(12.0)$ & $7(11.0)$ & $11(14.7)$ & $462(20.3)$ & $110(29.5)$ & $2(20.0)$ \\
$10: 30-13: 30$ & $17(34.0)$ & $3(4.7)$ & $5(6.7)$ & $512(22.6)$ & $58(15.5)$ & $2(20.0)$ \\
$13: 30-16: 30$ & $17(34.0)$ & $17(26.5)$ & $4(5.3)$ & $570(25.1)$ & $62(16.6)$ & $2(20.0)$ \\
16:30-19:30 & $5(10.0)$ & $34(53.1)$ & $3(4.0)$ & $340(15.0)$ & $19(5.1)$ & $4(40.0)$ \\
Total & $50(100.0)$ & $64(100.0)$ & $75(100.0)$ & $2.270(100.0)$ & $373(100.0)$ & $10(100.0)$ \\
\hline
\end{tabular}

Values in parentheses refer to the percentage of behaviour performed for time of day within each behaviour. $D N$, dehydrating nectar; $E$, excavating nest; $P A$, pre-flight warm-up; $R$, resting inside the nest; $V C$, returning to the nest from a foraging trip; $O$, others

carried out under mild temperatures, was concentrated in the late afternoon, when the ambient temperature started to decline. When excavating the nest, the bees showed a mean body temperature of around $29-30^{\circ} \mathrm{C}$ (Table III). Resting in the nest and nectar dehydration were concentrated at the hottest times of the day, with the mean ambient temperature around $30^{\circ} \mathrm{C}$, while the temperature of the bee reached close to $35^{\circ} \mathrm{C}$ (Tables II and III).

With regard to the mean body temperature of the bees, a pattern could be seen in temperature between the behaviour types, despite variations for each activity (Figures 4, 5 and 6; Table III). Bees at rest and digging the nest showed a similarly lower mean body temperature $\left(27\right.$ to $31^{\circ} \mathrm{C}$ ) compared to bees in pre-flight warm-up or returning to the nest after foraging $\left(28\right.$ to $35^{\circ} \mathrm{C}$ ) (Table III). For nectar dehydration, there was a wide variation in the body temperature of the carpenter bees $\left(28\right.$ to $38^{\circ} \mathrm{C}$ ) (Table III).

Returning to the nest after foraging was the activity with the highest mean body temperature in X. frontalis, while the lowest mean temperature was seen in the bees at rest inside the nest (Table III). The mean body temperature of bees returning to the nest after foraging differed significantly $(p<0.05)$ from the temperatures observed for the other activities, both in relation to the time of day, the month of observation and nest location (Figures 4, 5 and 6; Table III). The other types of behaviour showed similar mean body temperatures, with significant differences only in specific cases, as can be seen in Table II. Among the types of behaviour under evaluation, resting in the nest showed the highest correlation between mean body temperature and ambient temperature $(0.5483207, p<0.001)$ (Figure 7).

There was no significant difference in ambient temperature as a function of nest location $(p<$ 0.05 ), in the same way that no statistical difference $(p<0.05)$ was seen for activities carried out by the bees, comparing the mean body temperature between bees housed in the forest and those in the Xylocopary breeding facility, with the exception of resting in the nest (Figure 5; Table III). (Additional data are available in Online Resource 1.)

With regard to the time of year, the highest mean body temperatures were recorded during October and December, when the bees returned from the field (greater than $34^{\circ} \mathrm{C}$ ), and February, when dehydrating nectar (greater than $38{ }^{\circ} \mathrm{C}$ ) (Table IV). However, in terms of higher absolute body temperature, values above $40{ }^{\circ} \mathrm{C}$ were recorded each month for the behaviour of returning from foraging, reaching almost $47{ }^{\circ} \mathrm{C}$ for one event in September (Figure 6; Table IV). With the delay in rainfall, September, October and December corresponded to the peak of the dry season that year, and achieved the highest ambient temperatures (Table IV).

In addition to the more frequent types of behaviour, it was possible to see sporadic stressing behaviour, such as bees fighting at 


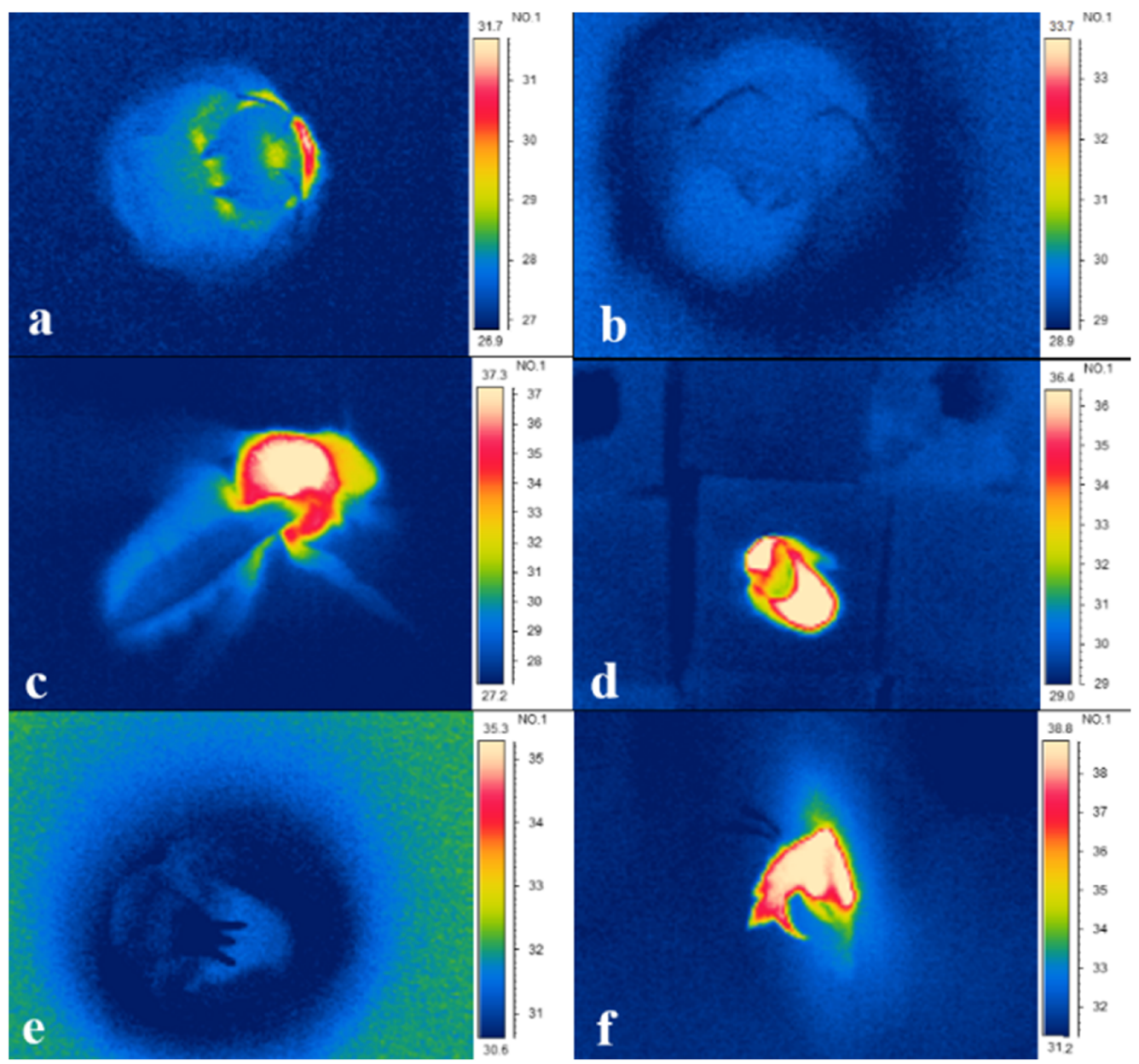

Figure 3. Thermographic images for frequent behaviour presented by Xylocopa frontalis : nest excavation (a), resting inside the nest (b), pre-flight warming (c), returning to the nest after foraging (d), dehydrating nectar received through trophallaxis (e) and dehydrating nectar immediately after returning from the field (f).

the entrance to the nest, responding to attacks by ants, warming up in the sun after a possible eviction from the nest, and audibly vibrating inside the excavated gallery (Figure 8). In these situations, there was a rapid increase in individual body temperature. In cases where the nests were attacked by ants or the bees were seen fighting another bee at the entrance to the nest, a fast rise in their thorax temperature to $5.35{ }^{\circ} \mathrm{C}$ and 4.65 ${ }^{\circ} \mathrm{C}$ above the ambient temperature could be seen respectively. One bee found on the ground was a young female, probably evicted from the nest by its mother, which remained in the sun for a few minutes and then took flight once the temperature of the thorax had increased from $30.8{ }^{\circ} \mathrm{C}$, to $36.1{ }^{\circ} \mathrm{C}$. Finally, a bee that suddenly started intense audible vibration inside the nest for no obvious reason, showed a $10.4{ }^{\circ} \mathrm{C}$ increase in thorax temperature (Figure 8).

\section{DISCUSSION/CONCLUSION}

The great majority of observations (approximately $80 \%$ ) showed the bees at rest inside the nest. This may be due to the fact that resting is a long-lasting activity in relation to the other activities, increasing the chances of this behaviour being seen where there are several Xylocopa 

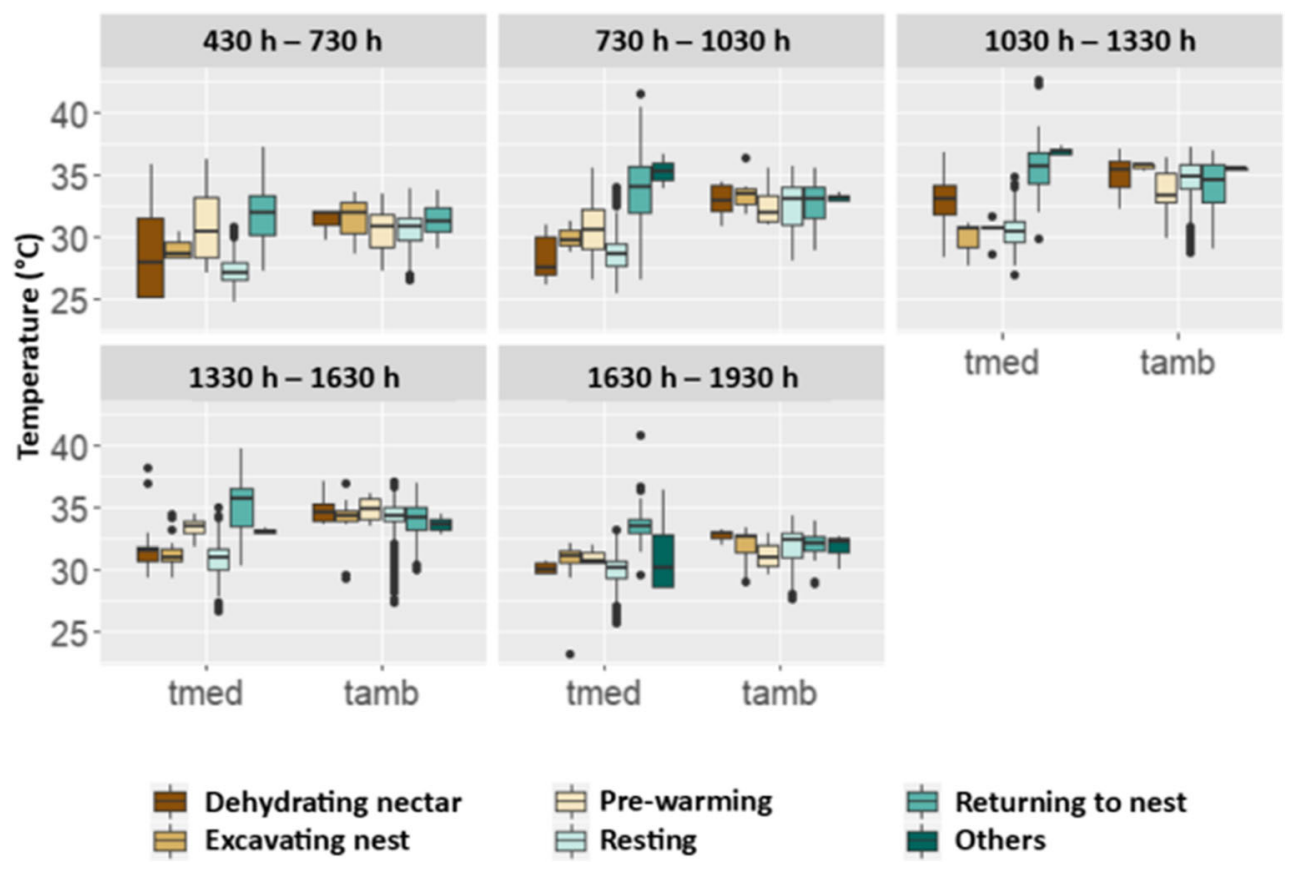

Figure 4. Mean ambient temperature and mean body temperature in Xylocopa frontalis when performing different types of behaviour in the nests at different times of the day.

Table II. Mean, maximum and minimum ambient temperatures for time of day, month of observation and nest location, in Fortaleza, Ceará, Brazil, from August 2018 to February 2019

\begin{tabular}{|c|c|c|c|c|}
\hline & & \multicolumn{3}{|c|}{ Ambient temperature } \\
\hline & & Maximum & Minimum & Mean \pm standard deviation \\
\hline \multirow[t]{5}{*}{ Period } & $04: 30-07: 30$ & 33.9 & 26.9 & $31.5 \pm 1.5^{\mathrm{a}}$ \\
\hline & 07:30-10:30 & 36.4 & 28.1 & $32.8 \pm 1.9^{\mathrm{c}}$ \\
\hline & $10: 30-13: 30$ & 37.2 & 28.8 & $33.0 \pm 1.9^{\mathrm{e}}$ \\
\hline & $13: 30-16: 30$ & 37.1 & 27.3 & $32.9 \pm 2.1^{\mathrm{d}}$ \\
\hline & $16: 30-19: 30$ & 34.3 & 27.6 & $31.8 \pm 1.5^{\mathrm{b}}$ \\
\hline \multirow[t]{6}{*}{ Month } & August & 37.1 & 28.6 & $33.1 \pm 2.0^{\mathrm{b}}$ \\
\hline & September & 37.2 & 26.6 & $33.7 \pm 2.3^{\mathrm{c}}$ \\
\hline & October & 35.9 & 27.3 & $33.3 \pm 1.9^{\mathrm{bc}}$ \\
\hline & December & 36.8 & 29.2 & $33.2 \pm 1.8^{\mathrm{b}}$ \\
\hline & January & 35.6 & 27.3 & $32.4 \pm 2.2^{\mathrm{a}}$ \\
\hline & February & 35.5 & 27.9 & $32.6 \pm 1.9^{\mathrm{a}}$ \\
\hline \multirow[t]{2}{*}{ Place } & Forest & 37.2 & 26.6 & $32.9 \pm 2.1^{\mathrm{a}}$ \\
\hline & Xylocopary & 36.9 & 28 & $32.8 \pm 2.1^{\mathrm{a}}$ \\
\hline
\end{tabular}




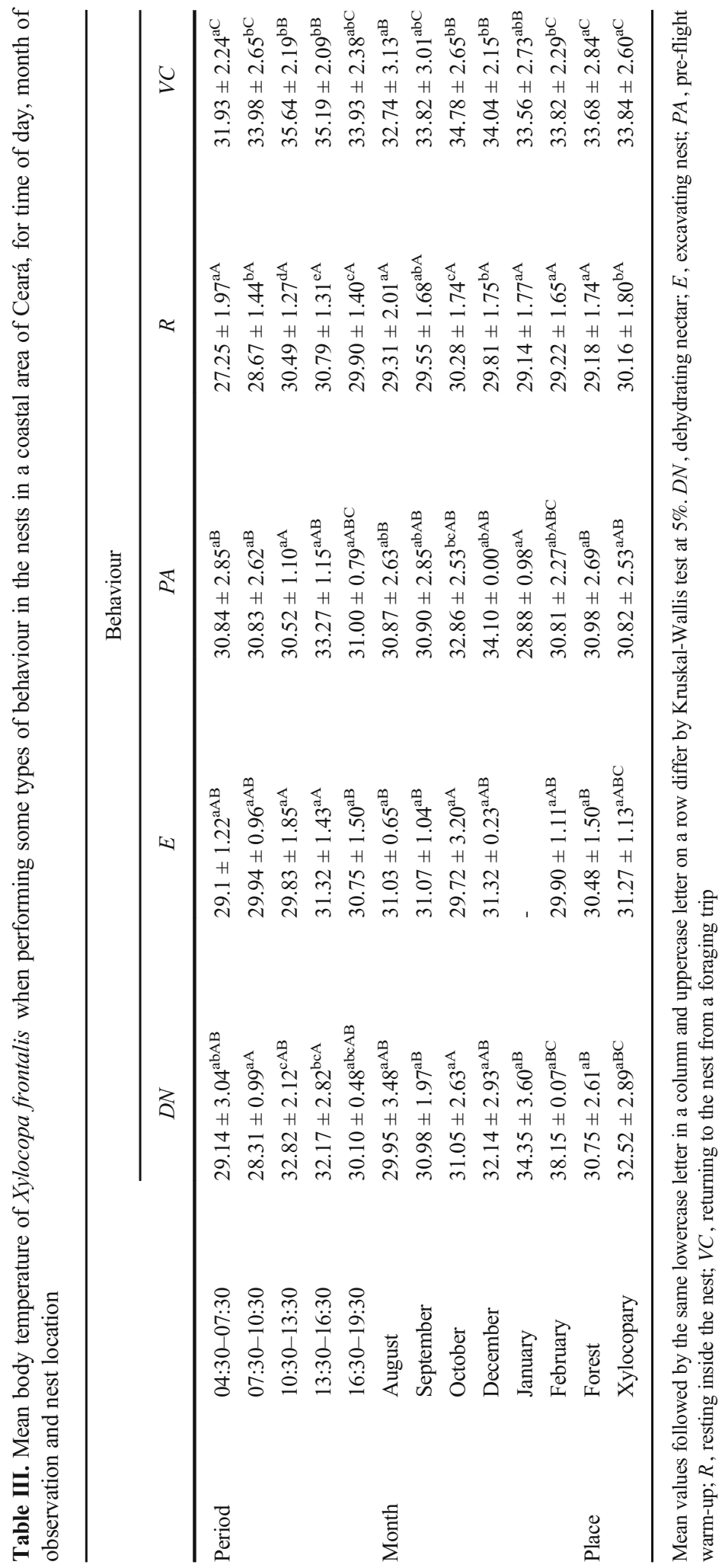



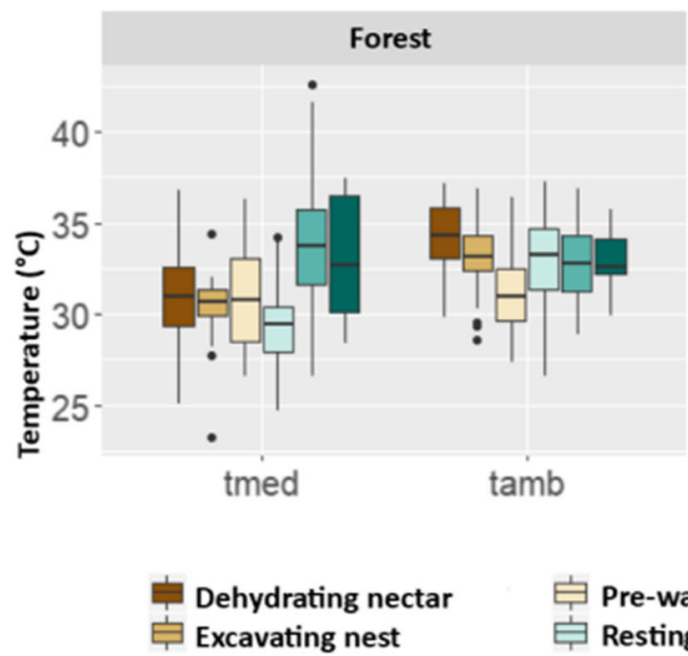

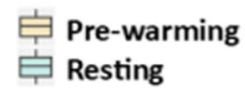

Xylocopary

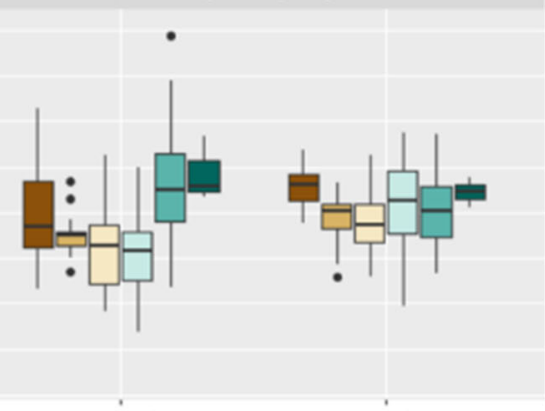

tmed tamb

Figure 5. Mean ambient temperature and mean body temperature of Xylocopa frontalis when performing different types of behaviour in the nests at different locations.

nests, as in this study (Camillo and Garofalo 1982; Freitas et al. 2017); or these bees, being solitary, producing few offspring and not accumulating considerable amounts of food resources (honey and pollen) in the nest, do not need to be so active in search of food (Oliveira-Filho and Freitas 2003; Silva et al. 2014); or even because it is an adaptive strategy to minimise activities that generate heat, especially at the hottest times of the day, as seen in other species from environments with high
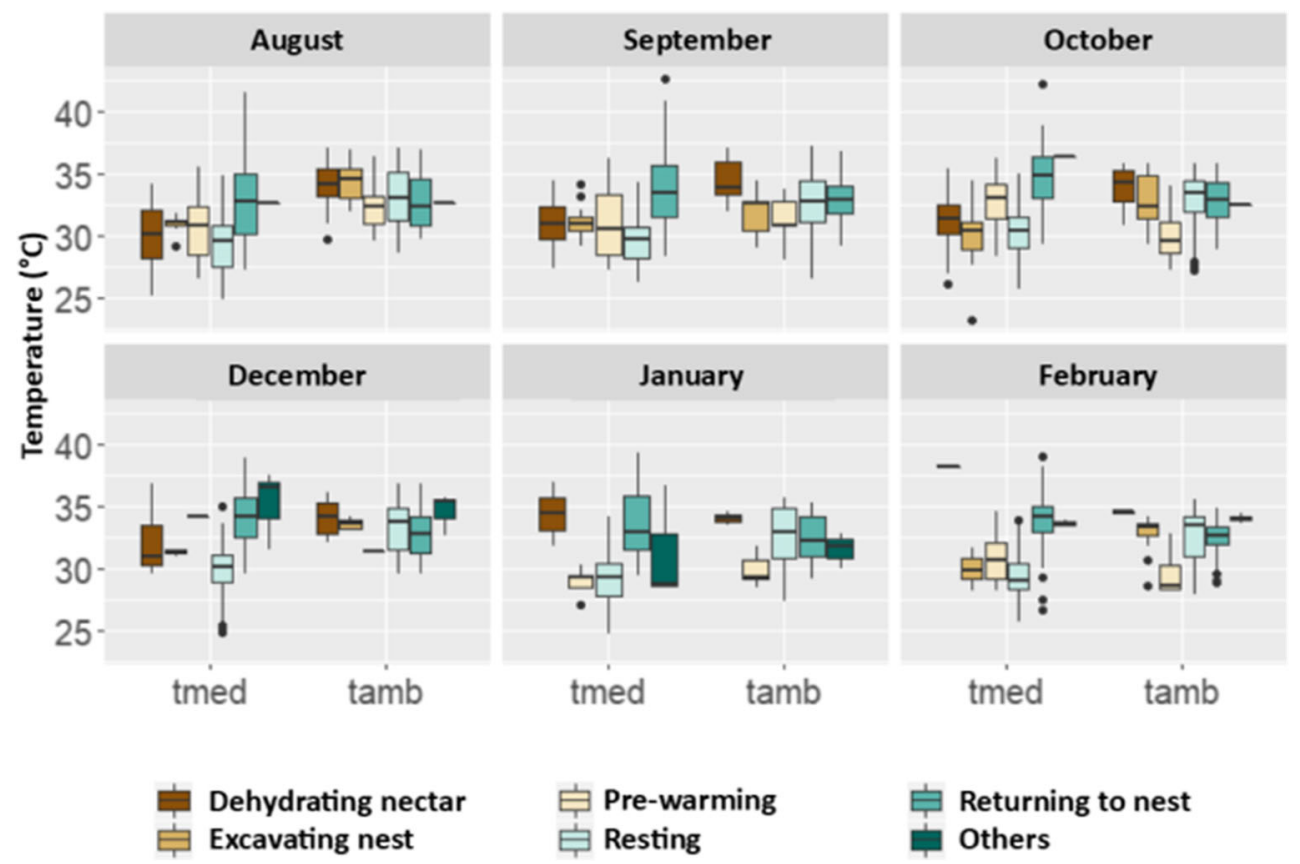

\section{Returning to nest Others}

Figure 6. Mean ambient temperature and mean body temperature of Xylocopa frontalis when performing different types of behaviour in the nests during different months of the year. 


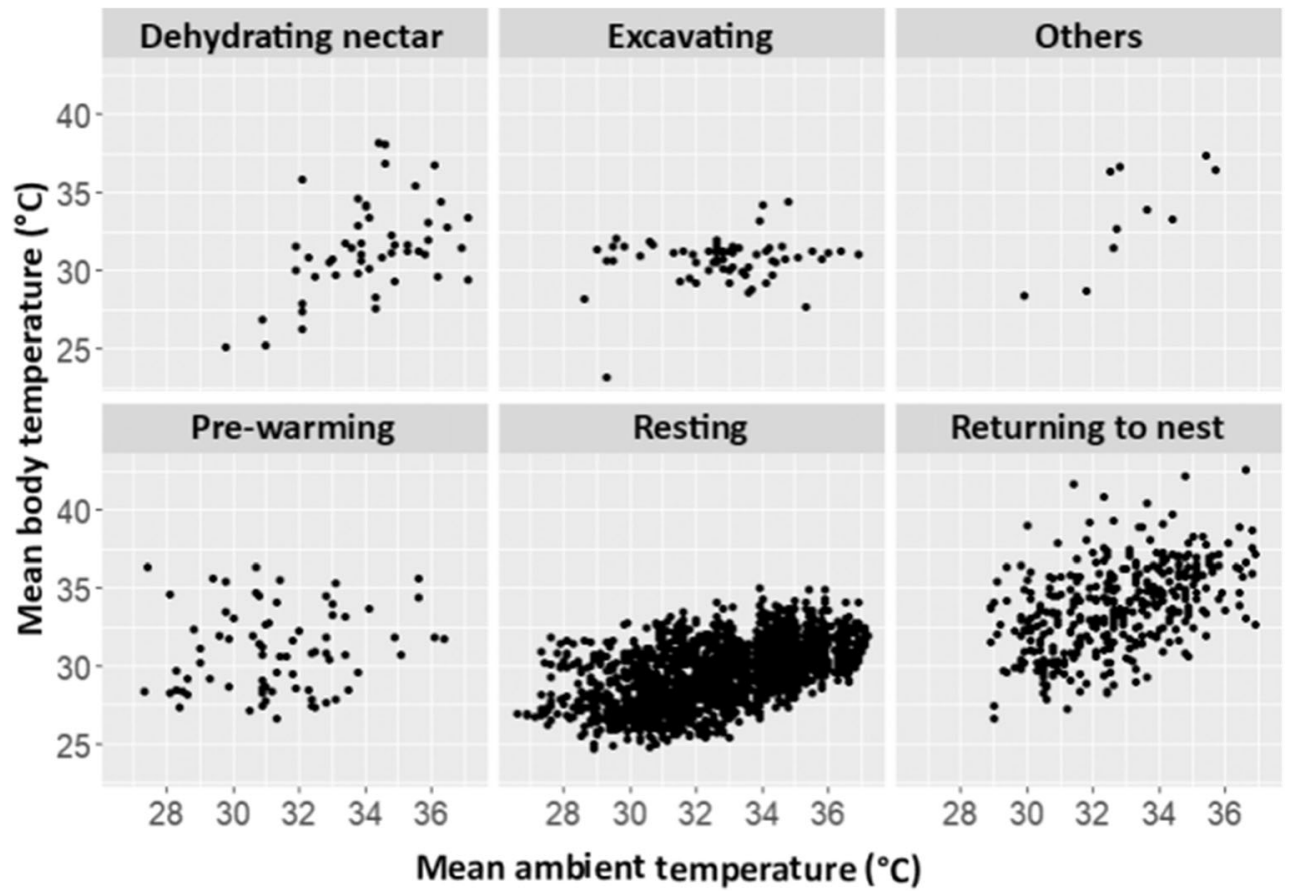

Figure 7. Correlation between the mean ambient temperature and mean body temperature of Xylocopa frontalis when performing different types of behaviour in the nests located in Fortaleza, Ceará, Brazil.

Table IV. Maximum and minimum body temperature for the different types of behaviour observed in Xylocopa frontalis housed in the nests in the coastal region of Ceará, for the month of observation and time of day

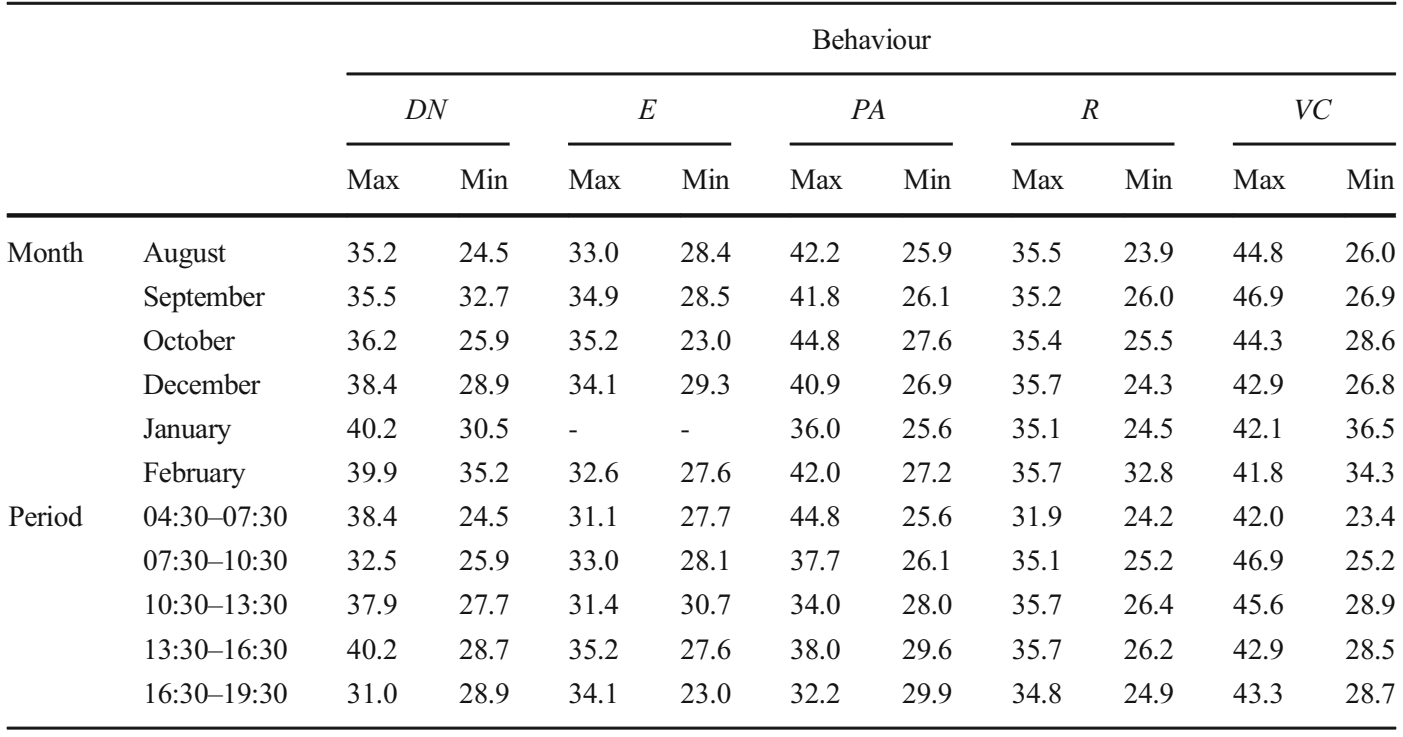

$D N$, dehydrating nectar; $E$, excavating nest; $P A$, pre-flight warm-up; $R$, resting inside the nest; $V C$, returning to the nest from a foraging trip 


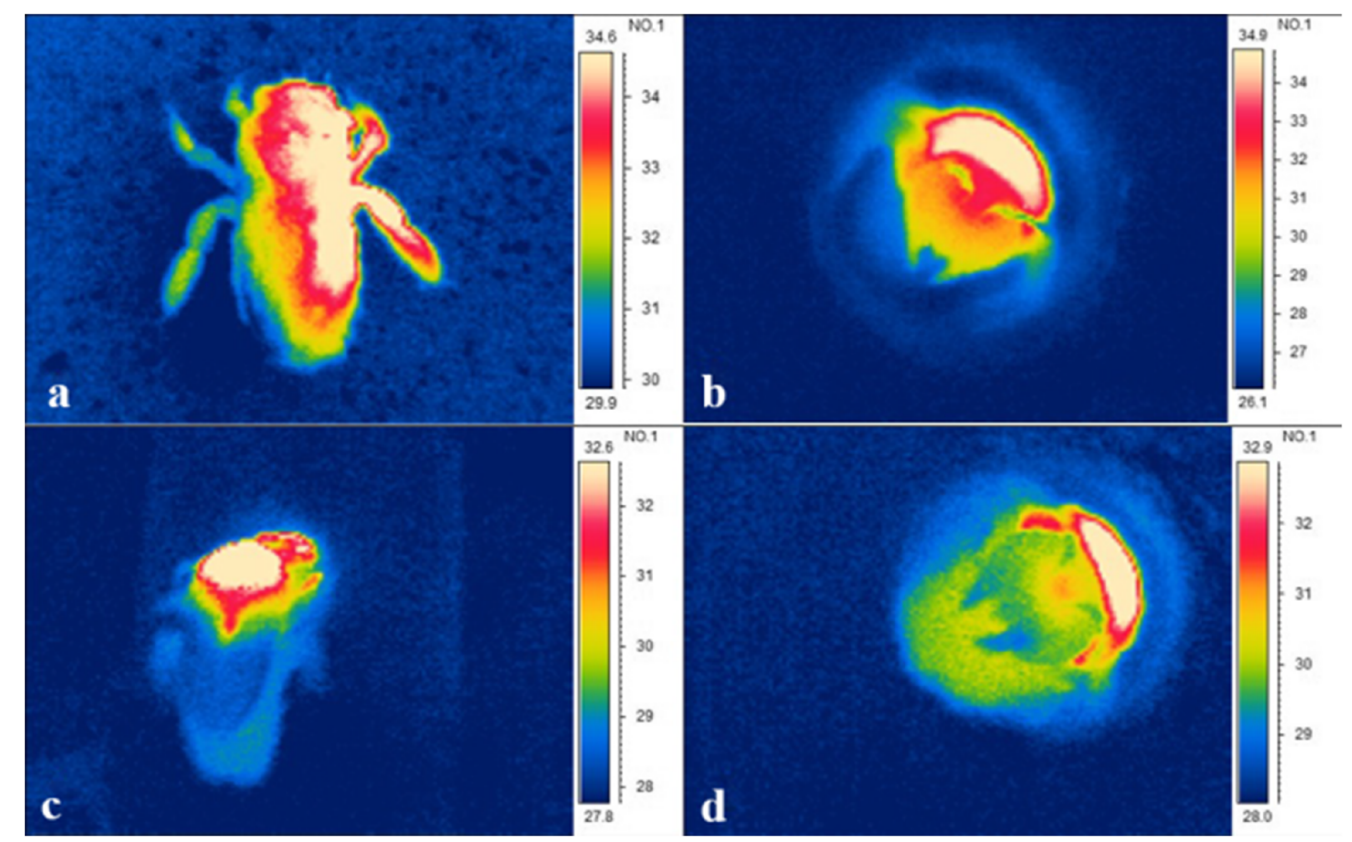

Figure 8. Thermographic images for occasional behaviour performed by Xylocopa frontalis : basking in the sun (a), under ant attack (b), fighting other bee at the entrance to the nest (c) and vibrating inside the nest (d).

temperatures (Heinrich and Buchmann 1986; Heinrich 1993).

In fact, activities that generate more body heat (foraging and pre-flight warm-up) were concentrated in the cooler hours of the day, while those that produce less or no body heat (rest and excavation of the nest) were more common at higher temperatures, corroborating the findings of Chappell (1982), and Heinrich and Buchmann (1985) for other species of Xylocopa . However, all behaviour types were seen throughout the day, suggesting that this species of carpenter bee may have preferential times for different activities, but reproductive needs and probably the availability of food in the field seem to be factors that cause them to carry out certain activities at times of the day which are less favourable to regulating body temperature.

With regard to thermoregulation, for most of the time, the bees kept their body temperature above the ambient temperature even when performing activities that generated little heat. The exception was when the bees were resting in the nest, which showed some correlation between body temperature and the ambient temperature. But this can be explained by the animals displaying temporal endothermy, being considered ectothermic when not performing any activity; when at rest, their body temperature remains close to the ambient temperature (Heinrich 1993; Heinrich and Buchmann 1986).

However, pre-flight warm-up is necessary in order to fly because the flight musculature of these bees does not function properly at temperatures below $30{ }^{\circ} \mathrm{C}$ (Heinrich 1993). In fact, the mean pre-flight warm-up temperatures seen were always slightly above this figure, although maximum values above $40{ }^{\circ} \mathrm{C}$ were recorded throughout the study period, except during January. Nevertheless, these higher values were observed during the early hours of the day, when the ambient temperature is still low. In large bees, internal heat generation is more efficient than in small bees. In contrast, loss of heat by convection is greater in bees with less body mass. As such, the efficient endothermy of Xylocopa, especially in the early hours of the morning, combined with the large body mass of these bees, allows them to forage under conditions which would be impossible for smaller bees, especially at low temperatures (Gerling et al. 1983; Somanathan and Borges 
2001; Silva et al. 2019). For the conditions of this study, when even before sunrise the ambient temperature remained above $23{ }^{\circ} \mathrm{C}$, low temperatures cannot be considered a limiting factor to these bees starting their activities, but show the need for pre-flight warm-up at temperatures that favour the correct functioning of the flight musculature, and minimise heat loss by convection when flying while the ambient temperature is below $30^{\circ} \mathrm{C}$. In this situation, the dark colour of the bee favours greater heat absorption when exposed to the sun, helping it to reach and maintain the minimum body temperature necessary for flight (Figure 8a).

On the other hand, the body temperature of the bees when they returned from field trips showed high mean values, reaching $35^{\circ} \mathrm{C}$, with maximum values greater than $42{ }^{\circ} \mathrm{C}$, reaching close to $47^{\circ} \mathrm{C}$. These figures probably explain the preference showed by the carpenter bee to forage during the coolest hours, avoiding the hottest times of the day. The high body temperature of these large bees when returning from the field is due both to the internal heat generated due to flight, resulting from the metabolism of the animal and by exposure to solar radiation (Chappell 1982; Baird 1986; Heinrich and Buchmann 1986; Corbet and Huang 2016). Despite this, the females of $X$. frontalis are coloured black, which may seem a disadvantage for bees living in regions of tropical climate under high temperatures and intense solar radiation (but see the above discussion on pre-flight warm-up). However, not only should the colour or body weight be considered in heat generation but also the environment where the bee lives and the phylogeny. It is possible that a flight system tolerant of extremely high working temperatures exists in bees living in warm environments that makes the bee capable of low rates of warm-up, even at relatively high ambient temperatures (Stone and Willmer 1989). Chappell (1982) states that the efficient loss of heat by convection during flight in species of Xylocopa, especially those that show little pubescence, would compensate for the heat gained due to the exposure of the black integument to solar radiation. Despite the existence of other heat-loss mechanisms, this seems to be the main and most efficient mechanism for this genus of bee (Chappell 1982; Baird 1986; Heinrich and Buchmann 1986; Volynchik et al. 2006). Referring to this, Heinrich and Buchmann
(1986) demonstrated that $X$. varipuncta flies faster under conditions of high air temperature, increasing its cooling by convection.

Xylocopa is able to transfer heat from the thorax, considered its thermogenic centre, to the head and abdomen, where heat loss occurs through convection (Baird 1986). This heat loss prevents overheating and allows the bee to forage under considerably higher temperatures. This transfer of heat to the head occurs passively, through conduction, but the passage of heat to the abdomen can occur actively, as bees have a mechanism for retaining heat in the thorax consisting of a series of loops in the aorta at the height of the petiole (Baird 1986; Heinrich 1993). Such a mechanism gives considerable control to the transfer of heat from the thorax to the abdomen. In this study, this action was seen in bees that required warming of the flight musculature, retaining heat generated in the thorax with little dissipation to the head (Figure $3 \mathrm{c}$ ), and in bees returning from foraging trips where the situation was the reverse, the bees needing to dissipate heat from the thorax to the abdomen (Figure 3d).

In addition to the loss of body heat through convection, carpenter bees are also able to lose heat by dehydrating nectar, which, due to the exposure of the collected resource to the air, causes a loss of heat through evaporative cooling (Sakagami and Laroca 1971; Bernardino and Gaglianone 2008). But a wide variation in the body temperature of carpenter bees was seen when they were dehydrating nectar. This happened because, despite $X$. frontalis behaving as a solitary species most of the time, young offspring stay in the nest for some days after emergence, interacting with their mother (parasocial behaviour). Therefore, in this situation, bees resting in the nest, for which the body temperature was close to that of the environment, dehydrated the nectar they received by trophallaxis from other bees (Figure 3e), and bees that returned to the nest after foraging also dehydrated nectar as a way of cooling down their dangerously high temperatures (Figure 3f).

Therefore, the high body temperatures shown by individuals returning from the field irrespective of the time of year or time of day, the concentration of foraging activities at the coldest times of the day, and evaporative cooling by evaporating the nectar to lose body heat, suggest that 
$X$. frontalis is well adjusted to the ecological conditions of tropical regions, but may face difficulties if the ambient temperature rises.

Despite there being no studies that show the limit for the maximum ambient temperature under which $X$. frontalis can thrive, Chappell (1982) found that the foraging pattern of $X$. californica is affected when the ambient temperature exceeds $41^{\circ} \mathrm{C}$. In the present study, conducted in a coastal area, the foraging activity of $X$. frontalis occurred at ambient temperatures ranging between 28.9 and $36.9{ }^{\circ} \mathrm{C}$. As such, the foraging pattern of $X$. frontalis should not be affected by the ambient temperature at any time. However, records from Discover Life, Global Information Biodiversity Facilities (GBIF), Species Link and WorldClim show that $X$. frontalis has not been found in neotropical areas where maximum temperatures reach $35^{\circ} \mathrm{C}$ or higher (Figure 1), and the long resting period seen in this study ( $80 \%$ of the observations) may be the result of the bees avoiding activities which might generate heat, especially foraging, during the hottest times of the day.

The IPCC (2013) points to potential increases of between 0.3 and $4.8^{\circ} \mathrm{C}$ in mean global temperature by 2080 , with the present area of natural occurrence of this species of carpenter bee being one of the most affected. In addition, studies of climate modelling have shown that increases in the mean ambient temperature due to climate change can reduce the areas suitable for the survival of $X$. frontalis by up to $47.9 \%$ (Giannini et al. 2013; Bezerra et al. 2019a). Currently, temperatures around or greater than $41{ }^{\circ} \mathrm{C}$ have been recorded at the hottest times of the day in some areas of the Brazilian countryside, and even extremely high temperatures of over $50{ }^{\circ} \mathrm{C}$ in full sunlight (Maia-Silva et al. 2015; Hrncir et al. 2019; INMET 2020). Moreover, in a study in this region with a small-sized tropical bee, Melipona subnitida, Hrncir et al. (2019) demonstrated that the flight muscles may increase the thoracic temperature of foragers by up to $10^{\circ} \mathrm{C}$ above the air temperature in the shade. If a similar increase in temperature occurs with $X$. frontalis, the thoracic temperature may reach a dangerously high $45^{\circ} \mathrm{C}$ at an ambient temperature of only $35^{\circ} \mathrm{C}$, explaining why the bee is not found where maximum temperatures reach this value or higher.
In addition, the pollination services offered to wild and agricultural plants by Xylocopa bees might also be compromised. For example, $X$. frontalis is one of the main pollinators of the yellow passion fruit (Passiflora edulis). Its flowers open at noon and close in the evening, requiring the transfer of large amounts of pollen during this short period to obtain large heavy fruit of commercial value (Oliveira-Filho and Freitas 2003). Currently, the carpenter bee risks overheating when visiting flowers at the hottest times of the day, because temperatures that are critical and lethal to insects are affected by the exposure time (Hrncir et al. 2019; Jørgensen et al. 2019). If average temperatures rise further, Xylocopa bees may be prevented from flying and pollinating the passion fruit under these environmental conditions, resulting in a plantpollinator mismatch (Silva and Freitas 2018; Bezerra et al. 2019a). X. frontalis adjusting to forage at higher temperatures is unlikely because species which already tolerate high temperatures are more sensitive to increases in the ambient temperature than species having a lower critical temperature (Rezende et al. 2014).

It can therefore be concluded that despite the bees of genus Xylocopa showing successful strategies and a refined thermoregulation mechanism that has allowed them to inhabit the desert, semiarid and tropical regions of the planet, future climate change, especially the rise in ambient temperature, can pose a serious risk to the survival of these bees, particularly $X$. frontalis . Further studies of critical and lethal temperatures, and thermoregulation mechanisms, combined with monitoring populations of this species, are necessary in order to conserve and develop forms of sustainable exploitation of this pollinator.

Supplementary Information The online version contains supplementary material available at https://doi.org/10.1007 /s13592-020-00824-8.

\section{ACKNOWLEDGEMENTS}

The authors wish to thank two anonymous reviewers for their comments and suggestions, which significantly improved this paper. 


\section{AUTHORS' CONTRIBUTION}

Both authors have contributed equally to this study.

Funding

Felipe J. Farias-Silva received Masters scholarship award from the Conselho Nacional de Desenvolvimento Científico e Tecnológico $(\mathrm{CNPq})$ in Brasilia, and Breno M. Freitas received sponsorship grant from the Productivity Research (302934/2010-3).

Data availability

All data generated or analysed during this study are included in this published article (and its supplementary information files).

\section{COMPLIANCE WITH ETHICAL STANDARDS}

Conflict of interest The authors declare that they have no conflict of interest.

La thermorégulation chez la grande abeille charpentière Xylocopa frontalis face au changement climatique dans les régions néotropicales

température corporelle / stratégie de butinage / réchauffement climatique / comportement de thermorégulation / tropiques

Thermoregulation bei der großen Holzbiene Xylocopa frontalis angesichts der Klimaveränderungen in den Neotropen

Körpertemperatur / Sammelstrategie / globale Erwärmung / Thermoregulationsverhalten / Tropen

\section{REFERENCES}

Baird J.M. (1986) A field study of thermoregulation in the carpenter bee Xylocopa virginica (Hymenoptera: Anthophoridae). Physiol. Zool. 59 (2), 157-168.

Bartomeus I., Ascher J.S., Wagner D., Danforth B.N., Colla S., Kornbluth S., Winfree, R. (2011) Climateassociated phenological advances in bee pollinators and bee-pollinated plants. Proc. Natl. Acad. Sci. 108 (51), 20645-20649.

Bernardino A.S., Gaglianone M.C. (2008) Distribuição de ninhos e hábitos de nidificação de Xylocopa ordinaria Smith (Hymenoptera, Apidae) em área de restinga no norte do Estado do Rio de Janeiro, Brasil. Rev. Brasil. Entomol. 52, 434-440.

Bezerra A.D.M. (2018) Impacto das mudanças climáticas na relação polinizador-cultura agrícola e alternativas para mitigar seus efeitos: o caso das abelhas Xylocopa spp. e o maracujá amarelo (Passiflora edulis ). Doctoral thesis, Universidade Federal do Ceará.

Bezerra A.D.M., Pacheco-Filho A.J., Bomfim I.G., Smagghe G., Freitas B.M. (2019a) Agricultural area losses and pollinator mismatch due to climate changes endanger passion fruit production in the Neotropics. Agric. Syst. 169, 49-57.

Bezerra A.D.M., Pacheco-Filho A.J., Bomfim I.G., Smagghe G., Freitas B.M. (2019b) Data relating to threats to passion fruit production in the Neotropics due to agricultural area loss and pollinator mismatch as consequence of climate changes. Data Brief. 23, 103802 .

Bishop J.A., Armbruster W.S. (1999) Thermoregulatory abilities of Alaskan bees: effects of size, phylogeny and ecology. Funct. Ecol. 13 (5), 711-724.

Brown M.J.F. et al. (2016) A horizon scan of future threats and opportunities for pollinators and pollination. Peer. J. 4, 2249.

Camillo E., Garofalo C.A. (1982) On the bionomics of Xylocopa frontalis (Oliver) and Xylocopa grisescens (Lepeletier) in southern Brazil: nest construction and biological cycle. Rev. Brasil. Biol. 42, 571-582.

Cavalcante M.C., Galetto L., Maués M.M., Pacheco-Filho A.J.S., Bomfim I.G.A., Freitas B.M. (2018) Nectar production dynamics and daily pattern of pollinator visits in Brazil nut (Bertholletia excelsa Bonpl.) plantations in Central Amazon: implications for fruit production. Apidologie, 49 (4),505-516.

Chappell M.A. (1982) Temperature regulation of carpenter bees (Xylocopa californica) foraging in the Colorado Desert of southern California. Physiol. Zool. 55 (3), 267-280.

Corbet S.A., Huang S. (2016) Small bees overheat in sunlit flowers: do they make cooling flights?. Ecol. Entomol. 41 (3), 344-350.

Dunn O.J. (1964) Multiple comparisons using rank sums. Technometrics. 6 (3), 241-252.

Elias M.A., Borges F.J., Bergamini L.L., Franceschinelli E.V., Sujii E.R. (2017) Climate change threatens pollination services in tomato crops in Brazil. Agric. Ecosyst. Environ. 239, 257-264.

Fick S.E., Hijmans R.J. (2017) WorldClim 2: new $1 \mathrm{~km}$ spatial resolution climate surfaces for global land areas. International Journal of Climatology 37 (12), 43024315.

Freitas B.M., Imperatriz-Fonseca V.L., Medina L.M., Kleinert A.M.P., Galleto L., Nates-Parras G., Quezada-Euán J.J.G. (2009) Diversity, threats and 
conservation of native bees in the Neotropics. Apidologie. 40, 332-346.

Freitas B.M., Oliveira-Filho J.H. (2003) Ninhos racionais para mamangava (Xylocopa frontalis) na polinização do maracujá-amarelo (Passiflora edulis ). Cienc. Rural. 33, 1135-1139.

Freitas B.M., Silva C.I., Bezerra A.D.M. (2017) A História Natural Ilustrada de um Polinizador: a abelha mamangava Xylocopa frontalis / The Illustrated Natural History of a Pollinator: the carpenter bee Xylocopa frontalis . A.B.E.L.H.A., São Paulo.

Gerling D., Hurd P.D., Hefetz A. (1983) Comparative behavioral biology of two Middle East species of carpenter bees (Xylocopa Latreille) (Hymenoptera: Apoidea). Smithson. Contrib. Zool. 369, j1-33.

Giannini T.C., Acosta A.L., Silva C.I., Oliveira P.E.A.M., Imperatriz-Fonseca V.L., Saraiva A.M. (2013) Identifying the areas to preserve passion fruit pollination service in Brazilian Tropical Savannas under climate change. Agric. Ecosyst. Environ. 171, 39-46.

Giannini T.C., Maia-Silva C, Acosta A.L., Jaffé R., Carvalho A.T., Martins C.F., Zanella F.C.V., Carvalho C.A.L., Hrncir M., Saraiva A.M., Siqueira J.O., Imperatriz-Fonseca, V.L. (2017). Protecting a managed bee pollinator against climate change: strategies for an area with extreme climatic conditions and socioeconomic vulnerability. Apidologie. 48,784-794.

Gimenes M., Figueiredo N. A., Santos A. H. P. (2006) Atividades relacionadas à construção e aprovisionamento de ninhos de Xylocopa subcyanea (Hymenoptera, Apidae) em uma área de restinga na Bahia, Brasil. Iheringia, Sér. Zool. 96 (3), 299-304.

Heinrich B. (1993) The hot-blooded insects: strategies and mechanisms of thermoregulation. Harvard University Press, Cambridge.

Heinrich B., Buchmann S. L. (1986) Thermoregulatory physiology of the carpenter bee, Xylocopa varipuncta. J. Compo Physiol. 56, 557-562.

Heinrich B., Esch H. (1994) Thermoregulation in bees. Am. Sci. 82 164-170.

Herrera J.M., Ploquin E.F., Rodríguez-Pérez J., Obeso J.R., Araújo M.B. (2014) Determining habitat suitability for bumblebees in a mountain system: a baseline approach for testing the impact of climate change on the occurrence and abundance of species. J. Biogeogr. 41, 700712.

Hrncir M., Maia-Silva C., Teixeira-Souza V.H.S., Imperatriz-Fonseca V.L. (2019) Stingless bees and their adaptations to extreme environments. J. Comp. Physiol. A 205, 415-426. https://doi.org/10.1007 /s00359-019-01327-3

INMET (2020) Normais Climatológicas do Brasil [Online]. http://www.inmet.gov.br/portal/index.php?r= clima/normaisClimatologicas. Accessed 22 Jan 20.

IPCC (2013) In: Qin D., Plattner G.-K., Tignor M., Allen S.K., Boschung J., Nauels A., Xia Y., Bex V., Midgley P.M. (Eds.), Climate Change 2013: The Physical Science Basis. Contribution of Working Group I to the Fifth Assessment Report of the Intergovernmental
Panel on Climate Change Stocker. Cambridge University Press, Cambridge.

IPECE (2019) Perfil Básico Municipal, [online]. http://ipecedata.ipece.ce.gov.br/ipece-data-web/. Accessed 15 July 2019.

Jørgensen L.B., Malte H., Overgaard J. (2019) How to assess Drosophila heat tolerance: Unifying static and dynamic tolerance assays to predict heat distribution limits. Funct. Ecol. 33, 629-642, DOI:https://doi. org/10.1111/1365-2435.13279

Junqueira C.N., Yamamoto M., Oliveira P.E., Hogendoorn K., Augusto S.C., (2013) Nest management increases pollinator density in passion fruit orchards. Apidologie 44 (6), 729-737.

Klein A.-M., Freitas B.M., Bomfim I.G.A., Boreux V., Fornoff, F., Oliveira M.O. (2020) Insect Pollination of Crops in Brazil: A Guide for Farmers, Gardeners, Politicians and Conservationists. Nature Conservation and Landscape Ecology, Albert-Ludwigs University Freiburg, Freiburg.

Klein A.M., Vaissière B.E., Cane J.H., Steffan-Dewenter I., Cunningham S.A., Kremen C., Tscharntke T. (2007) Importance of pollinators i changing landscapes for world crops. Proc. Biol. Sci. 274 (1608), 303-313.

Kruskal W.H., Wallis A. (1952) Use of ranks in onecriterion variance analysis. J. Am. Stat. Assoc. 47, 583-621.

Maia-Silva C., Hrncir M., Silva C.I., Imperatriz-Fonseca V.L. (2015) Survival strategies of stingless bees (Melipona subnitida) in an unpredictable environment, the Brazilian tropical dry forest. Apidologie 46, 631-643. https://doi.org/10.1007/s13592-0150354-1

Marchi P., Melo G. R. (2010) Biologia de nidificação de Xylocopa (neoxylocopa) frontalis (Olivier) (Hymenoptera, Apidae, Xylocopini). Oecol. Aust. 14 (1), 210-231.

Maués M.M., Krug C., Wadt L.H.O., Drumond P.M., Cavalcante M.C., Santos A.C.S. (2015). A castanheira-do-brasil: avanços no conhecimento das práticas amigáveis à polinização. Embrapa Amazônia Oriental, Belém.

Meeus I., Vercruysse V., Smagghe G. (2012) Molecular detection of Spiroplasma apis and Spiroplasma melliferum in bees. J. Invertebr. Pathol. 109 (1), 172-174.

Muniz J.P.O., Bomfim I.G.A., Corrêa M.C.D.M., Freitas B.M. (2019) Floral biology, pollination requirements and behavior of floral visitors in two species of pitaya. Rev. Cienc. Agron. 50 (4), 640-649.

Oliveira-Filho J.H., Freitas, B.M. (2003) Colonização e biologia reprodutiva de mamangavas (Xylocopa frontalis ) em um modelo de ninho racional. Cienc, Rural. 33 (4), 693-697.

Oliver T.H., Marshall H.H., Morecroft M.D., Brereton T., Prudhomme C., Huntingford C. (2015) Interacting effects of climate change and habitat fragmentation on drought sensitive butterflies. Nat. Clim. Chang. 5 (10), 941-945. 
Ollerton J., Winfree R., Tarrant S. (2011) How many flowering plants are pollinated by animals?. Oikos. 120 (3), 321-326.

Pereira M., Garófalo C.A. (2010) Biologia da nidificação de Xylocopa frontalis e Xylocopa grisescens (Hymenoptera, Apidae, Xylocopini) em ninhos-armadilha. Oecol. Aust. 14 (1), 193-209.

Polce C., Garratt M.P., Termansen M., RamirezVillegas J., Challinor A.J., Lappage M.G., Somerwill K.E., 2014. Climate-driven spatial mismatches between British orchards and their pollinators: increased risks of pollination deficits. Glob. Change Biol. 20 (9), 2815-2828.

Potts S.G. et al. (2016) Safeguarding pollinators and their values to human well-being. Nature 540 (7632), 220229.

Rasmont P., Iserbyt S. (2012) The Bumblebees Scarcity Syndrome: are heat waves leading to local extinctions of bumblebees (Hymenoptera: Apidae: Bombus)?. Ann. Soc. Entomol. Fr. 48 (3-4), 275-280.

Rezende E.L., Castañeda L.E, Santos M. (2014) Tolerance landscapes in thermal ecology. Funct. Ecol. 28:799809

Sakagami S.F., Laroca S. (1971) Observations on the bionomics of some neotropical Xylocopini bees, with comparative biofaunistic notes (Hymenoptera, Anthophoridae). J. Fac. Sci. (18) 57-127.

Settele J., Bishop J., Potts S.G. (2016) Climate change impacts on pollination. Nat. Plants 2, 16092.

Silva C.I., Freitas B.M. (2018) Rearing carpenter bees (Xylocopa spp.) for crop pollination: a case study with passionfruit (Passiflora edulis) In: Roubik (ed.) The pollination of cultivated plants: a compendium for practitioners. FAO, Rome.

Silva C.I., Marchi, P., Aleixo K.P., Nunes-Silva B., Freitas B.M., Garófalo C.A., Imperatriz-Fonseca V.L., Oliveira P.E.A.M., Alves-dos-Santos I. (2014) Manejo dos Polinizadores e Polinização de Flores do Maracujazeiro. Instituto de Estudos Avançados da Universidade de São Paulo, São Paulo.
Silva J.G., Meneses, H.M., Freitas, B.M. (2019) Foraging behavior of the small-sized stingless bee Plebeia aff. flavocincta. Revista Ciência Agronômica 50 (3), 484492.

Somanathan H., Borges R. M. (2001). Nocturnal Pollination by the Carpenter Bee Xylocopa tenuiscapa (Apidae) and the Effect of Floral Display on Fruit Set of Heterophragma quadriloculare (Bignoniaceae) in India. Biotropica. 33 (1), 78-89.

Soroye P., Newbold T., Kerr J. (2020) Climate change contributes to widespread declines among bumble bees across continents. Science. 367, 685-688.

Stabentheiner A., Schmaranzer, S. (1987) Thermographic determination of body temperatures in honey bees and hornets: calibration and applications. Thermology. 2, 563-572.

Stabentheiner A., Kovac H., \& Schmaranzer, S. (2007) Thermal behaviour of honeybees during aggressive interactions. Ethology. 113 (10), 995-1006.

Stone G.N. (1993) Endothermy in the solitary bee Anthophora plumipes : independent measures of thermoregulatory ability, costs of warm-up and the role of body size. J. Exp. Biol. 174 (1), 299-320.

Stone G.N. (1994) Activity patterns of females of the solitary bee Anthophora plumipes in relation to temperature, nectar supplies and body size. Ecol. Entomol. 19 (2), 177-189.

Stone G.N., Willmer P.G. (1989) Warm-ip rates and body temperatures in bees: the importance of body size, thermal regime and phylogeny. Journal of Experimental Biology 147, 303-328.

Volynchik S., Plotkin M., Ermakov N.Y., Bergman D.J., Ishay J.S. (2006) Presence of a thermoregulatory hot spot in the prothorax of the large carpenter bee and the bumble bee. Microsc. Res. Techniq. 69 (11), 903-912.

Publisher's note Springer Nature remains neutral with regard to jurisdictional claims in published maps and institutional affiliations. 